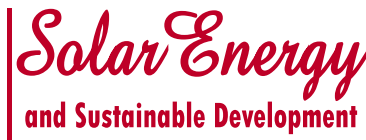 \\ Refereed, biannual scientific journal Issued by
}

\section{Projected Avoided Costs of Conventional Power Plants in Libya Using Wind Energy}

\author{
W.I. Abuzend ${ }^{1}$, W.A. El-Osta ${ }^{2}$, M.A. Ekhlat ${ }^{3}$, E. Borass ${ }^{4}$ \\ Technical Institute of Mechanical and Electrical Eng. weramzenid a vahoo com. \\ 'Center for Solar Energy Research and Stwdies, e wedada hotmail.com \\ Electric Engineering Department. University of Tripoli. tibya cigrela hotmail com. \\ ${ }^{4}$ General Electric Company of Libya ezz abourassablycos.com
}

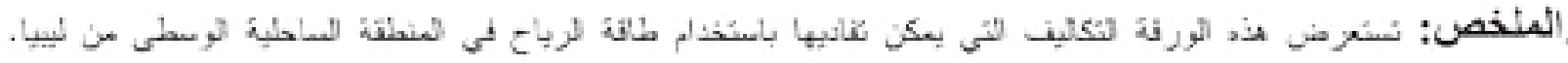

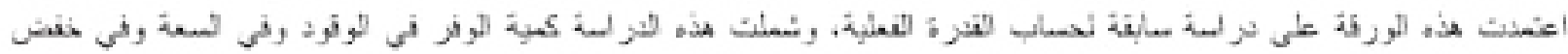

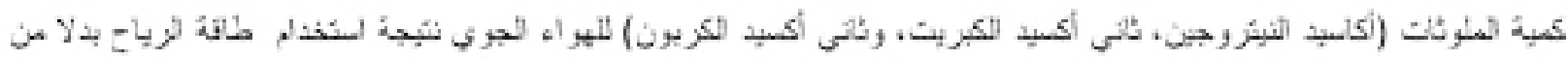

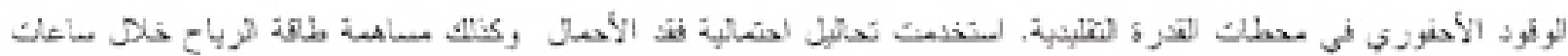

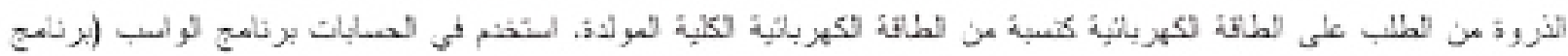

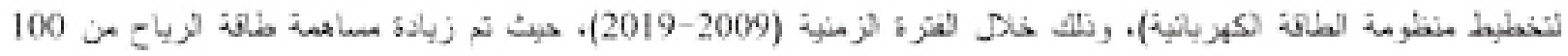

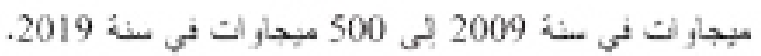

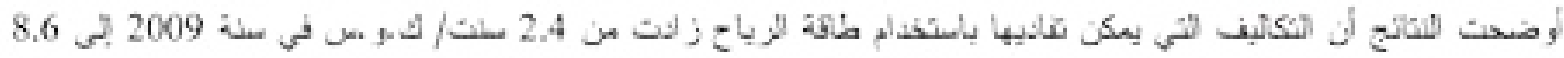

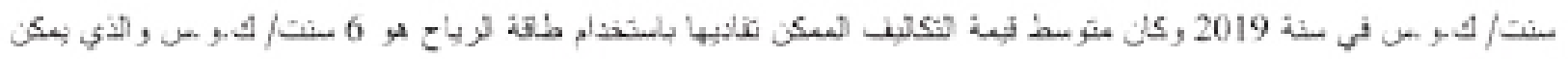

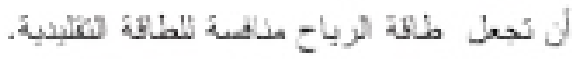

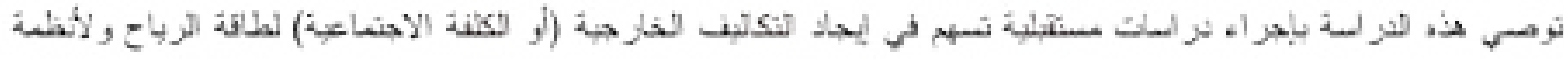

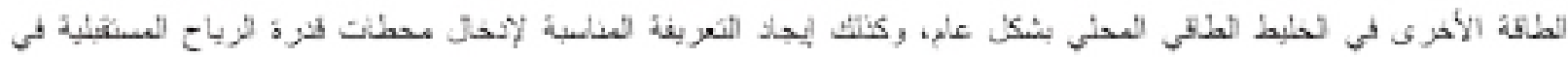

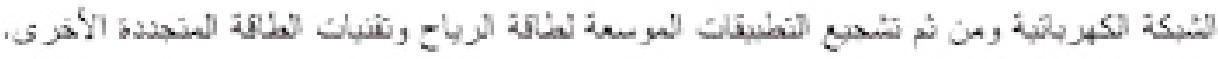

Abstract: This paper investigates the costs that can be avoided by using wind energy in the central coastal area of Libya. The investigation of the capacity eredit was performed in a previous work. The analysis included fuel saving, capacity saving and emission reduction $\left(\mathrm{NO}_{2}, \mathrm{SO}_{2}\right.$ and $\left.\mathrm{CO}_{2}\right)$ to the atmosphere. The avoided costs were translated into equivalent energy costs of wind energy systems. The evaluation was conducted using the reliability (LOLP) analysis and the contribution of wind system during peak demand to the utility total electricity generation system. The calculations were carried out using WASP (Wien Automatic System Planning Package) for the proposed period of 2009 . 2019 where wind power installation would increase from $100 \mathrm{MW}$ in 2009 to $500 \mathrm{MW}$ in 2019.

The results showed that the avoided costs of wind energy will increase from $2.4 \mathrm{c} / \mathrm{kWh}$ in 2009 to 8.6 $\mathrm{c} / \mathrm{kWh}$ in 2019 . The mean value of the avoided costs of wind energy over the 10 -year period is $6 \mathrm{c} / \mathrm{kWh}$, which would make wind power economically competitive with conventional power plants in Libya.

Further investigations of detailed external costs of all energy systems in the national energy mix, as well as the feed in tariff, are recommended and should be introduced to the national energy sectors in order to promote implementation of wind energy and other renewable energy technologies.

Keywords -Wind Energy, Capacity Credit, Environmental Benefits, Avoided Costs. 


\section{INTRODUCTION}

The primary environmental value of electricity generated from wind energy systems is that the wind offsets emissions that would be generated by conventional fossil fueled power plants. These emissions include sulfur dioxide $\left(\mathrm{SO}_{2}\right)$, nitrogen oxides $\left(\mathrm{NO}_{x}\right)$, carbon dioxide $\left(\mathrm{CO}_{2}\right)$, particulates, slag and ash. The amount of emissions saved via the use of wind energy depends on the type of power plants that is replaced by the wind system, type of fuel used and the emissions' control systems installed on the power plants. So, the main benefits of using wind energy are the avoided emissions and therefore, the emission savings in addition to other external costs that are raised from conventional power plants. The other avoided costs result primarily from the reduction of fuel that would be consumed by a conventional generating plant. They may also result from a decrease in total conventional generating capacity that a utility requires.

To analyze the environmental and health benefits of using wind energy, we need to know the specific emissions of fossil fuelbased electricity generation replaced thereby. These can be derived by dividing the absolute emissions produced by a type of fossil-fuel in kilotons of each emission per year, by the amount of electricity generated from this fuel in $\mathrm{kWh}$ per year. In general, the emissions avoided by wind energy depend on the specific emissions from each type of fossil fuel-based electricity generation facility, the fuel mix, and the percentage of each fuel replaced by wind energy.

The calculation of fuel saving is a complicated process. The type and amount of fuel savings depend on many factors such as the energy mix in the electrical generating system, requirements for 'spinning reserves', and operating characteristics of the power plants (such as efficiency or heat rate as a function of component load). Also, it depends on the penetration level of wind energy delivered to the system.

The avoided capital costs depend on wind power capacity that can displace conventional power plants or the capacity credit of wind power. The capacity credit depends, among other factors, on the penetration level of wind power integrated into the energy system.

It is well known that the power sector is the main contributor to green house effect and other environmental problems. It accounts for $40 \%$ of the global $\mathrm{CO}_{2}$ emissions [1], and on the national level, it accounted for $39.5 \%$ of $\mathrm{CO}_{2}$ emissions in 2006 [2]. $\mathrm{CO}_{2}$ is the main contributor to green house gases (GHG's). It is expected that these gases will increase the mean global temperature by $0.4-5.8 \mathrm{C}$ over this century [3]. A UN study shows that sea level has risen by $10-20 \mathrm{~cm}$ during the last century and by $9-12 \mathrm{~cm}$ in the last 50 years [3]. This study, also, indicates that the environmental damage will reach $\$ 300$ billion by 2050. Another study conducted by World Health Organization (WHO) indicates that 160,000 persons / year are dying due to climate change [3]. By 2020, EWEA's projection for wind power development in Europe is that 180 GW of wind power will be installed in EU-27. This will generate about $477 \mathrm{TWh} / \mathrm{yr}$, and will save 215 Million tons of $\mathrm{CO}_{2}, 261000$ tons of $\mathrm{SO}_{2}$ and 333,000 tons of $\mathrm{NOx}[3,4]$. The amount of annual avoided fuel cost is 20.5 billion Euros and the annual avoided $\mathrm{CO}_{2}$ cost is 8.2 billion Euros [4]. The cost of producing electricity from coal or oil would double and the cost of electricity from gas would increase by $30 \%$ if external costs in the form of damage to the environment and health were taken into consideration [3]. Studies show that the wind energy external cost is less than 0.26 Euro cents/ $\mathrm{kWh}$, while for coal fired generation, it is 2-15 Euro cents/kWh. [3]. In 2007, 10.2 billion Euro have been avoided in EU-27, by wind power generation as external costs [5].

On the global level, the total avoided costs through the use of wind energy 
amounted to 1.8 billion Euro in the year 2000 and the projected avoided costs will be 25 billion Euro/yr in 2020[1]. In 2008, globally, wind energy saved 157 million tons of $\mathrm{CO}_{2}$ ( $16 \%$ of total Kyoto targets for 2008) [6]. The $\mathrm{CO}_{2}$ emission avoided costs (in year 2000) at different countries, assuming an average wind speed of $6 \mathrm{~m} / \mathrm{s}$ inland and $6.9 \mathrm{~m} / \mathrm{s}$ on coastal sites and a capacity credit of wind power of $25 \%$. ranges between a lowest value in U.S.A. (23 cent Euro for coal and natural gas (N.G.) respectively) and highest value in Japan (4.5- 8.5 cent Euro for coal and N.G. respectively) [7].

This paper concentrates on total avoided costs (fuel savings, capacity savings, and emission savings) that could be achieved by using wind energy to replace conventional power plants in Libya at different wind energy penetration levels and its projection during the next decade.

\section{INFORMATION OF POWER GENERATION UNITS}

The avoided costs were calculated using estimated data of the electricity generating system and electricity consumption in Libya for the years 2009, 2014 and 2019. The influence of the changes in the penetration level of wind power on avoided costs was investigated. Then, the avoided costs over a period of 10 years (2009-2019) were analyzed. Finally, a mean value is given for the total avoided cost of wind energy over this period of 10 years.

\subsection{Maintenance and forced outage for the generation units}

There are mainly three types of conventional power plants in the General Electricity Company of Libya (GECOL) which are steam turbines (ST), gas turbines (GT) and combined cycle gas turbines (CCGT). The Maximum conversion efficiency, forced outage rate and duration of annual maintenance for these power generation units are shown in table 1, [8].
Table 1: The forced outage and maintenance period for power generation units in Libya [8].

\begin{tabular}{cccc}
\hline Type of unit & $\begin{array}{c}\text { Maximum } \\
\text { efficiency } \\
(\%)\end{array}$ & $\begin{array}{c}\text { Forced } \\
\text { outage } \\
\text { rate }(\%)\end{array}$ & $\begin{array}{c}\text { Maintenance } \\
\text { period } \\
\text { (weeks) }\end{array}$ \\
\hline Steam turbine & 39 & 7 & 5 \\
Gas turbine & 35 & 7 & 5 \\
Combined cyele & 51 & 10 & 5 \\
\hline
\end{tabular}

\subsection{Fuel consumption}

Fuel is not required to produce wind power. When wind energy is produced, it saves significant amounts of fuel costs in the form of coal, gas and oil that would otherwise have been needed for power production. GECOL is using two types of fuel for power generation; natural gas (NG) and heavy fuel oil (HFO). The specific gravity and heating value of these types of fuel are shown in table 2.

Table 2: The specific gravity and heating value of two types of fuel [8].

\begin{tabular}{ccc}
\hline Type of fuel & Heating value & $\begin{array}{c}\text { Specific } \\
\text { gravity }\end{array}$ \\
\hline $\begin{array}{c}\text { Heavy fuel oil } \\
\text { (HFO) }\end{array}$ & $10640 \mathrm{kcal} / \mathrm{kg}$ & $0.922 \mathrm{~kg} / \mathrm{L}$ \\
$\begin{array}{c}\text { Natural gas } \\
\text { (NG) }\end{array}$ & $9072 \mathrm{kcal} / \mathrm{m}^{3}$ & $0.670 \mathrm{~kg} / \mathrm{m}^{3}$ \\
\hline
\end{tabular}

\subsection{Environmental aspects}

The environmental aspects that are considered for the calculation of the avoided costs by wind energy are the emissions of $\mathrm{CO}_{2}, \mathrm{SO}_{2}$ and $\mathrm{NO}_{x}$ of the fossil fuel thermal units. Other environmental aspects such as: the production of solid waste, noise and heat discharges were not considered. However, this study concentrated on 'environmental' costs raised from fossil fuel power production that contribute to the acid rain problems and the anticipated problems of global warming and other climatic changes.

There are no local records for the emission rates of the power plants, except for the total $\mathrm{CO}_{2}$ emission from all energy sectors, which was estimated as 58.3 million metric tons in 2008 [9]. So it was assumed that the emissions are similar to other countries. Figures from these countries, 
especially neighboring countries such as Egypt $[10,11]$, were used in this study. The adopted values of these emissions for Libyan power plants are shown in table 3. The estimation of the emission avoided costs is based on international studies. Mainly these studies are either based on assessing damages to health and environment or assessing emission reduction technologies that could be utilized to power generation plants. In this study the second tool was used, details are available in [12].

Table 3: The emission values for the two types of fuel that are used in power generation units in Libya

\begin{tabular}{cccc}
\hline $\begin{array}{c}\text { Type of } \\
\text { fuel }\end{array}$ & $\begin{array}{c}\mathrm{CO}_{2} \\
\text { emission } \\
(\mathrm{kg} / \mathrm{MWh})\end{array}$ & $\begin{array}{c}\mathrm{SO}_{2} \\
\text { emission } \\
(\mathrm{kg} / \mathrm{MWh})\end{array}$ & $\begin{array}{c}\mathrm{NO}_{\mathrm{X}} \\
\text { emission } \\
(\mathrm{kg} / \mathrm{MWh})\end{array}$ \\
\hline Natural gas & 510.8 & 0.045 & 0.765 \\
Fuel oil & 752.4 & 5.4 & 1.8 \\
\hline
\end{tabular}

WASP (Wien Automatic System Planning Package) software was used in the calculation of fuel consumption for all generation units that were considered in this study. The calculation was performed for the period (2009-2019).

\section{WIND POWER PRODUCTION SIMULATION AT THE SELECT - ED SITES}

In order to calculate the capacity saving (or capacity credit) and then the avoided capital costs of the conventional power plants, it is essential to calculate the hourly production of electricity by the proposed wind plants. The hourly wind power production was simulated in three selected sites (Benina, Ejdabia, Sirt) [13]. These sites are located at middle coast of Libya. The longitude, latitude and altitude of these sites are shown in table 4 . The wind power produced at these sites was simulated by using five selected types of wind turbines with sizes of $50 \mathrm{~kW}, 75 \mathrm{~kW}, 1 \mathrm{MW}, 1.5 \mathrm{MW}$, and $2 \mathrm{MW}$.

The calculations of the capacity factor for the three sites for different types of wind turbines and the estimation of capacity credit for different penetration levels of wind power in Libya were conducted in a previous work [13]

Table 4: Topological coordinates of the selected sites [13]

\begin{tabular}{lccccc}
\hline Station & $\begin{array}{c}\text { Latitude } \\
\mathrm{N}^{\circ}\end{array}$ & $\begin{array}{c}\text { Longitude } \\
\mathrm{E}^{\circ}\end{array}$ & $\begin{array}{c}\text { Altitude } \\
\text { (m asl) }\end{array}$ \\
\hline Benina & 32 & 05 & 20 & 16 & 132 \\
Ejdabia & 30 & 43 & 20 & 16 & 6 \\
Sirt & 31 & 12 & 16 & 35 & 13 \\
\hline
\end{tabular}

The result of the capacity factor for the three regions for different types of wind turbines is shown in table 5 and the estimation of capacity credit for wind power in Libya is shown in table 6, [13].

Table 5: The capacity factor for the three sites for different types of wind turbines [13]

\begin{tabular}{lccccc}
\hline \multicolumn{1}{c}{ Site } & $2 \mathrm{MW}$ & $1.5 \mathrm{MW}$ & $1 \mathrm{MW}$ & $0.75 \mathrm{MW}$ & $0.5 \mathrm{MW}$ \\
\hline Benina & 0.16 & 0.20 & 0.22 & 0.18 & 0.18 \\
Ejdabia & 0.11 & 0.13 & 0.14 & 0.12 & 0.12 \\
Sirt & 0.21 & 0.25 & 0.28 & 0.24 & 0.24 \\
\hline
\end{tabular}

Table 6: The capacity credit for wind power in Libya [13]

\begin{tabular}{ccc}
\hline $\begin{array}{c}\text { Installed wind } \\
\text { power }\end{array}$ & $\begin{array}{c}\text { Capacity } \\
\text { credit } \\
\text { (MW) }\end{array}$ & $\begin{array}{c}\text { Capacity credit } \\
\text { (\% of nominal } \\
\text { wind power) }\end{array}$ \\
\hline 100 & 50 & 50.0 \\
250 & 96 & 38.4 \\
500 & 103 & 20.6 \\
\hline
\end{tabular}

\section{INPUT FIGURES FOR CALCULATING AVOIDED COSTS}

The costs avoided by wind energy in three sites are evaluated for the near future (2009-2019). Therefore input figures are needed for the electricity consumption and the electricity production system in the future.

To evaluate the economic value of wind energy, assumptions need to be made for the fuel prices, capital costs, operation and maintenance costs and emission reduction costs.

\subsection{Fuel prices}

It is always difficult to predict future fuel prices since they depend on many related 
factors, and most of these predictions are uncertain. This study was performed in 2009 and according to GECOL price scenarios, the fuel prices are assumed according to table 7 .

Table 7: The fuel prices (50 S/barrel of oil) assumed in this study [8]

\begin{tabular}{lc}
\hline \multicolumn{1}{c}{ Type of fuel } & (cents\$/Gcal) \\
\hline Heavy fuel oil (HFO) & 2167 \\
Natural gas (NG) & 2921 \\
\hline
\end{tabular}

\subsection{Capital costs}

The capital cost of the conventional power generation units of the different sizes in GECOL are shown in table 8.

Table 8: The capital cost of power zeneration units [8]:

\begin{tabular}{ccc} 
Type & $\begin{array}{c}\text { Size } \\
\text { (MW) }\end{array}$ & $\begin{array}{c}\text { Capital cost } \\
(\mathbf{S} / \mathrm{kW})\end{array}$ \\
\hline Combined cycle & 1000 & 750 \\
gas turbine & 520 & 760 \\
(CCGT) & 350 & 780 \\
& 350 & 800 \\
\hline Gas turbine & 250 & 430 \\
(GT) & 150 & 525 \\
\hline Steam turbine & 500 & 1100 \\
(ST) & 350 & 1200 \\
\hline
\end{tabular}

\subsection{Operation and Maintenance Costs}

The operation and maintenance costs of the generators are shown in table 9.

Table 9: Estimation of O\&M costs for power generation units [8]:

\begin{tabular}{ccc}
\hline $\begin{array}{c}\text { Groups of } \\
\text { Generation units }\end{array}$ & $\begin{array}{c}\text { Fixed } \\
\text { O\&M costs } \\
(\mathrm{S} / \mathrm{kWh})\end{array}$ & $\begin{array}{c}\text { Variable } \\
\text { O\&M Costs } \\
(\mathrm{S} / \mathrm{kWh})\end{array}$ \\
\hline $\begin{array}{c}\text { Gas } \\
\text { turbinc }>100 \mathrm{MW}\end{array}$ & 0.11 & 1.67 \\
$\begin{array}{c}\text { Gas } \\
\text { turbine }<100 \mathrm{MW} \\
\text { Stcam }\end{array}$ & 0.26 & 1.84 \\
turbine $>100 \mathrm{MW}$ \\
$\begin{array}{c}\text { Steam } \\
\text { turbine }<100 \mathrm{MW}\end{array}$
\end{tabular}

\subsection{Emission reduction costs}

In order to evaluate the emission reduction costs, it is necessary to consider the chemical analysis and the emission rate of these fuels.

\subsubsection{Chemical analysis of fuel}

The Chemical analysis of Heavy fuel oil ( $\mathrm{HFO}$ ) is shown in table 10, while the chemical analysis of natural gas (NG) is shown in table 11.

Table 10: The Chemical analysis of Heavy fuel oil (HFO) used in power generation units in Libya

\begin{tabular}{cc}
\hline Content & $\begin{array}{c}\text { Percentage weight } \\
(\text { Wt. \%) }\end{array}$ \\
\hline Carbon & $86.0 \%$ \\
Hydrogen & $10.5 \%$ \\
Sulfurs & $3.00 \%$ \\
Oxygen & $0.05 \%$ \\
Nitrogen & $0.05 \%$ \\
Water & $0.20 \%$ \\
Ash & $0.20 \%$ \\
\hline
\end{tabular}

Table 11: The Chemical analysis of natural gas (NG) used in power generation units in Libya.

\begin{tabular}{cc}
\hline Content & $\begin{array}{c}\text { Percentage weight } \\
(\text { Wt. \%) }\end{array}$ \\
\hline Carbon & $75 \%$ \\
Hydrogen & $25 \%$ \\
Total & $100 \%$ \\
\hline
\end{tabular}

\subsubsection{Emission Rate}

In order to evaluate the emission rate, it is necessary to determine the emission coefficients of $\mathrm{CO}_{2}, \mathrm{SO}_{2}$ and $\mathrm{NO}_{2}$ for the fuel used in thermal units.

There are other environmental parameters, such as the production of solid waste, noise and heat discharges. However, in this study the 'environmental' costs of fossil fuel power production are restricted to the emission to the atmosphere that 
contributes to the acid rain problems and the anticipated problem of climatic change.

The emission rates of $\mathrm{NO}_{x}, \mathrm{SO}_{2}$ and $\mathrm{CO}_{2}$ were calculated according to the procedures and guidelines followed by international firms such as the Intergovernmental Panel on Climate Change (IPCC), UN framework convention on climate change (UNFCCC) and TUV considering the chemical analysis of the fuels (tables 10 and 11), and oxidation factor of 0.99 for $\mathrm{HFO}$ and 0.995 for $\mathrm{NG}$ recommended by IPCC [14-18]. The results are presented in table 12 .

Table 12: The emission rate by different types of fuel.

\begin{tabular}{cccc}
\hline \multirow{2}{*}{ Type of fuel } & \multicolumn{3}{c}{ Emission rate $(\mathrm{kg} / \mathrm{kg}$ fec $)$} \\
\cline { 2 - 4 } & $\begin{array}{c}\mathrm{NO}_{x} \\
\text { Emission }\end{array}$ & $\begin{array}{c}\mathrm{SO}_{2} \\
\text { Emission }\end{array}$ & $\begin{array}{c}\mathrm{CO}_{2} \\
\text { Emission }\end{array}$ \\
\hline $\begin{array}{c}\text { Heavy fuel oil } \\
\text { (HFO) }\end{array}$ & 0.005640 & 0.04 & 3.17 \\
\hline $\begin{array}{c}\text { Natural gas } \\
\text { (NG) }\end{array}$ & 0.001250 & 0.00 & 2.01 \\
\hline
\end{tabular}

4.4. Emission reduction costs for $\mathrm{NO}_{x}$ $\mathrm{SO}_{2}$ and $\mathrm{CO}_{2}$

There are no local records for the emission reduction technologies and therefore the emission reduction costs of the local power plants. So it was assumed that the emission reduction technique costs in other countries could be adopted [19].

No reduction techniques have been applied for $\mathrm{CO}_{2}$, but several studies have outlined some recovery techniques and $\mathrm{CO}_{2}$ storage possibilities. The cost figures for avoided $\mathrm{NO}_{x}$ and $\mathrm{SO}_{2}$ emissions which were adopted in this study are shown in table 13.

Table 13: The emission reduction costs for $\mathrm{NO}_{4}, \mathrm{SO}_{2}$ and $\mathrm{CO}_{2}[19]$

\begin{tabular}{cc}
\hline Type of emission & $\begin{array}{c}\text { Emission reduction costs } \\
(\mathrm{S} / 1000 \mathrm{~kg})\end{array}$ \\
\hline $\mathrm{NO}_{\mathrm{X}}$ & 400 \\
$\mathrm{SO}_{2}$ & 1120 \\
$\mathrm{CO}_{2}$ & 25 \\
\hline
\end{tabular}

5. METHODOLOGY OF EVALUAT ING THE AVOIDED COSTS IN LIBYA

The avoided costs were calculated using estimated data of the electricity generating system and electricity consumption in Libya for a period of 10 years (2009-2019). WASP (Wien Automatic System Planning Package) software was used to calculate the capacity savings, fuel savings and emission savings in order to determine the total avoided costs in conventional power plants when wind power plants are used. The work was performed at GECOL and all data required for the analysis were provided by GECOL. as mentioned in related sections in this paper.

The work was performed according to the following steps:

1. Calculation of the capacity value: the capacity value can be evaluated by two methods:

a) The contribution of the wind system during peak demand on a utility is assessed over a period of 10-years and the average power at these times was defined as the capacity value.

b) The loss of load probability (LOLP) or loss of load expectation (LOLE) is calculated, initially with no wind generators in the system. It is then recalculated with wind generation on the system and then conventional plant capacity is subtracted until the initial level of LOLP is obtained. The capacity of the subtracted power is the capacity value of the wind power.

Both methods give similar results and both methods were used to calculate the capacity savings and therefore, the avoided costs that can be accomplished by the use of wind energy in Libya.

2. Calculation of the fuel and emission savings: WASP (Wien Automatic System Planning Package) software was used to simulate electricity production of all the generating systems and therefore to simulate the fuel consumption and the 
related amounts of environmental emissions. The amounts of fuel savings and emission savings due to the use of wind energy are calculated for different wind power penetration levels, as mentioned in previous sections.

Two scenarios were performed according to the following steps:

1- WASP (Wien Automatic System Planning Package) software was used to calculate all required information about conventional generation units system for the period (2009-2019) without using wind energy case.

2- WASP software was used to calculate all required information about conventional generation units system for the year (2009) using wind energy for each penetration level of wind power (100MW-250MW- $500 \mathrm{MW}$ ) that contributed to the peak load on the national utility in the year 2009 .

3- WASP software was used to calculate all required information about conventional generation units system (with wind energy) for each penetration level with $100 \mathrm{MW}$ wind power in year the 2009 . $250 \mathrm{MW}$ wind power in the year 2014 and with $500 \mathrm{MW}$ wind power in the year 2019 that will contribute to the peak load of the national utility in the years $(2009$, 2014, 2019).

4- From differences between steps ( 1 and 2) in the first scenario, and steps ( 1 and 3 ) in the second scenario, the capacity saving and fuel saving were calculated, as well as the fuel consumption which was used to calculate the emission saving of $\left(\mathrm{NO}_{2}, \mathrm{SO}_{2}, \mathrm{CO}_{2}\right)$ over the period of this study (2009-2019).

\section{DISCUSSION OF THE RESULTS}

The calculations were performed considering two-scenarios.

The first scenario considered the influence of wind power penetration in one year (2009), where 3 values of wind penetration (100MW, 250MW and 500MW) were tested and the avoided costs were evaluated, using the forecast figures for the year 2009. The calculations of fuel savings for the two types of fuel used in the power plants were conducted and the expected amounts of fucl savings are shown in table 14. The results of the fuel savings, capacity savings, and emission savings are shown in table 15 for three different wind penetration levels (100 MW, $250 \mathrm{MW}, 500$ $\mathrm{MW}$ ) and the results for avoided costs (fuel, capacity, emission and total avoided costs), expressed as savings per unit energy, are presented in figure 1.

Table 14: The amount of fucl saving $(\mathrm{kg})$ as a function of wind power penetration for the year 2009

\begin{tabular}{ccc}
\hline Wind power & \multicolumn{2}{c}{ Fuel saving $\left(10^{6} \mathrm{~kg}\right)$} \\
\cline { 2 - 3 } penetration(MW) & $\begin{array}{c}\text { Natural gas } \\
\text { (NG) }\end{array}$ & $\begin{array}{c}\text { Heavy fuel } \\
\text { oil (HFO) }\end{array}$ \\
\hline 100 & 14.5 & 1.4 \\
250 & 28.7 & 3.2 \\
500 & 30.8 & 3.2 \\
\hline
\end{tabular}

Table 15: The fuel, capacity and emission savings (dollars) as a function of wind power penetration for the year 2009

\begin{tabular}{ccccc}
$\begin{array}{c}\text { Wind } \\
\text { power }\end{array}$ & $\begin{array}{c}\text { Energy } \\
\text { generated } \\
\text { pyenetration }\end{array}$ & $\begin{array}{c}\text { Fuel } \\
\text { saving }\end{array}$ & $\left.\begin{array}{c}\text { Capacity } \\
\text { saving }\left(\mathrm{C}_{\mathrm{C}}\right)\end{array}\right)$ & $\begin{array}{c}\text { Emission } \\
\text { saving }\left(\mathrm{C}_{\mathrm{E}}\right)\end{array}$ \\
$\left(10^{\circ} \mathrm{S}\right)$ & $\left(10^{\circ} \mathrm{S}\right)$ \\
(MW) & $(\mathrm{GWH})$ & $5)$ & & \\
\hline 100 & 292.6 & 5.8 & 0.3 & 0.91 \\
250 & 567.2 & 11.6 & 0.3 & 1.86 \\
500 & 612.1 & 12.4 & 0.3 & 1.97 \\
\hline
\end{tabular}

From table 15, it can be noticed that the highest saving is the fuel saving, followed by emission savings, then the capacity saving for the three wind penetration levels. Also, it is clear from this table that the capacity saving is constant for the three wind power penetration levels.

Figure 1 indicates that the total avoided costs (including avoided fuel, capacity and emission costs) are almost the same for the three penetration levels of wind power in the first scenario, since there is no change in load, plant mix, fuel mix or plant efficiencies of the conventional power plants. 


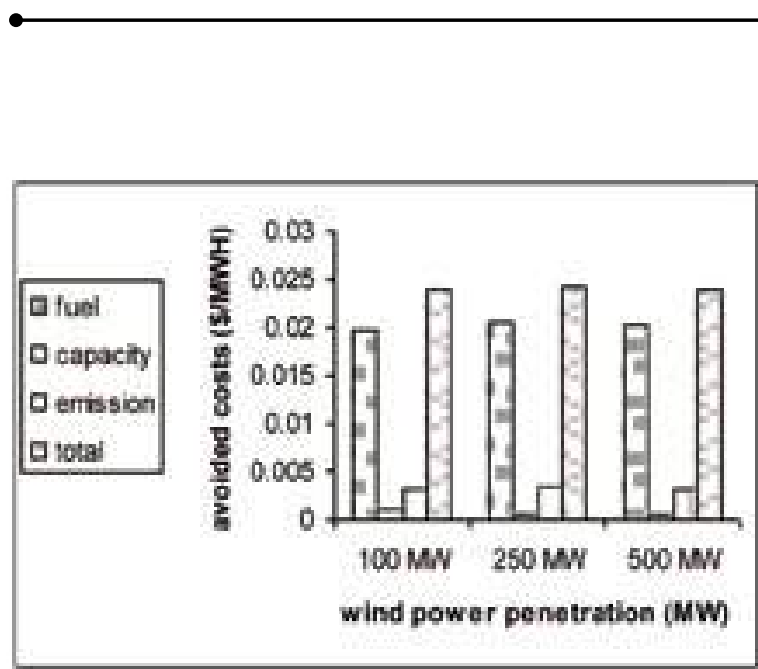

Figure 1: The avoided costs as a function of wind power penetration, evaluated for the year 2009.

The second scenario considered the influence of wind power penetration over a period of ten years (2009-2019). It was assumed that the wind power penetration will increase from $100 \mathrm{MW}$ in 2009 to 250 MW in 2014 and $500 \mathrm{MW}$ in 2019. The avoided costs for these three specific years: 2009. 2014 and 2019 were investigated, and they were compared with the avoided costs of the first scenario. During this period (2009-2019) many parameters will change in the conventional power plants, for example the installed capacity, plant mix, unit efficiencies and the load.

The avoided emissions of $\mathrm{NO}_{\mathrm{x}}, \mathrm{SO}_{2}$, and $\mathrm{CO}_{2}$ over this period (2009-2019) are shown in figure 2. This figure indicates that the $\mathrm{NO}_{\mathrm{X}}$ and $\mathrm{CO}_{2}$ emissions are increasing over the years 2009, 2014 and 2019 while the avoided emissions of $\mathrm{SO}_{2}$ are decreasing over the years 2009 to 2014 and equal zero in 2019. The reason of this reduction of $\left(\mathrm{SO}_{2}\right)$ is the GECOL strategy of decreasing the use of (HFO) for power generation units over the years 2009 to 2014 and discontinuing its use after the year 2014, in addition to the trend of utilizing (NG), which does not contain sulfur, for power generation.

The expected fuel, capacity, and emission savings (dollars) of the second scenario are shown in table 16 and the avoided costs over this period, expressed as savings per unit of energy or per $\mathrm{kWh}$, are presented in figure 3.

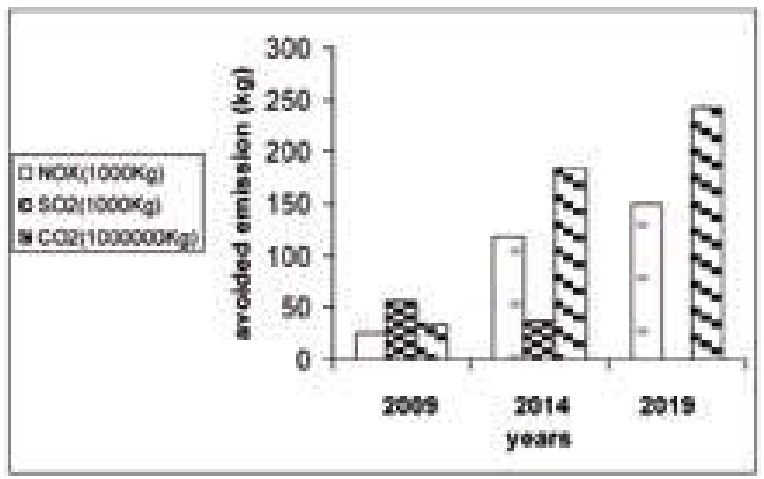

Figure 2: The avoided emissions of $\mathrm{NO},\left(10^{2}\right.$ $\mathrm{kg}), \mathrm{SO}_{2}\left(10^{3} \mathrm{~kg}\right)$ and $\mathrm{CO}_{2}\left(10^{6} \mathrm{~kg}\right)$ over the period (2009-2910).

Table 16: The fuel, capacity and emission savings (in 2009 dollars) as a function of wind power penetration over the period (2009-2019)

\begin{tabular}{|c|c|c|c|c|c|}
\hline $\begin{array}{r}\text { Year } \\
1 \\
1\end{array}$ & $\begin{array}{c}\text { Wind } \\
\text { Power } \\
\text { Penetration } \\
\text { (MW) }\end{array}$ & $\begin{array}{l}\text { Energy } \\
\text { generatec } \\
\text { by wind } \\
\text { (GWH) }\end{array}$ & $\begin{array}{l}\text { Fuel } \\
\text { dsaving } \\
\left(\mathrm{C}_{1}\right) \\
\left(10^{6} \mathrm{~S}\right)\end{array}$ & $\begin{array}{c}\text { Capacity } \\
\text { saving } \\
\left(\mathrm{C}_{\mathrm{C}}\right) \\
\left(10^{\circ} \mathrm{S}\right)\end{array}$ & $\begin{array}{c}\text { Emission } \\
\text { Saving } \\
\left(\mathrm{C}_{\mathrm{E}}\right) \\
\left(10^{\circ} \mathrm{S}\right)\end{array}$ \\
\hline 2009 & 100 & 292.6 & 5.8 & 0.3 & 0.91 \\
\hline 2014 & 250 & 567.2 & 34.4 & 0.7 & 4.69 \\
\hline 2019 & 500 & 612.1 & 45.6 & 1 & 6.10 \\
\hline
\end{tabular}

In the second scenario, it could be noticed that the fuel, capacity and environmental savings in dollars and accordingly the avoided costs per kWh will increase with the increase of wind power penetration over the period (2009-2019), as indicated in table 16 and in figure 3 respectively because it is expected that major changes will occur in the plant mix, type of fuels, plant efficiencies and load over this period. Also, it is clearly indicated from table 16, that the highest saving is the fuel saving, followed by emission saving then to a less extent the capacity saving. Therefore, from figure 3 , it could be noticed that the highest avoided cost is the fuel avoided cost, and then the emission followed by the capacity avoided cost.

The estimated average cost that will be avoided in the second scenario during the period $(2009-2019)$ is $6 \mathrm{cents} / \mathrm{kWh}$. 


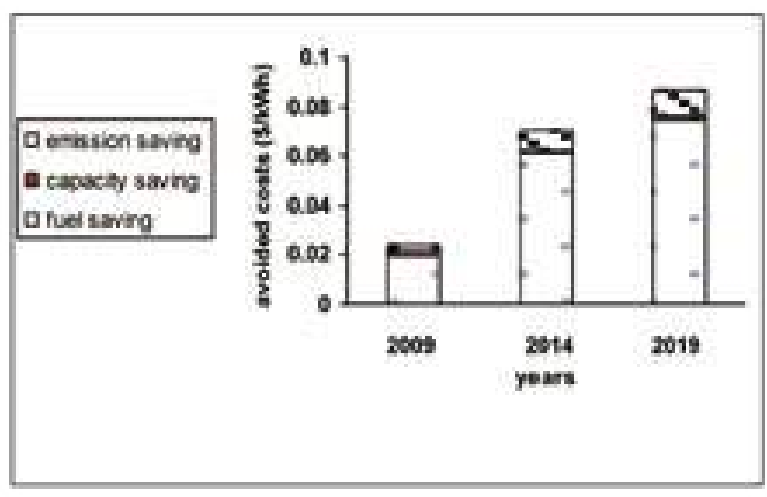

Figure 3: The avoided costs of fuel, capacity and emissions for the period (2009-2019)

\section{CONCLUSIONS AND RECOMMEND ATIONS}

The costs that could be avoided if wind energy is utilized at different penetration levels over the period 2009-2019 have been investigated by analyzing the savings in fuel, capacity and emissions. These avoided costs have been expressed as amount of avoided costs per unit of electric energy produced by conventional power plants.

The calculations were carried out for the year 2009 with wind power penetrations (100MW, 250MW, 500MW) and then the calculations were carried out for the years 2009, 2014 and 2019 with wind power penetrations (100, 250 and 500MW) respectively. The results showed that the avoided costs of wind energy will increase from $2.4 \mathrm{c} / \mathrm{kWh}$ in 2009 to $8.6 \mathrm{c} / \mathrm{kWh}$ in 2019. The average value of the avoided costs of wind energy over the 10-year period is $6 \mathrm{c} / \mathrm{kWh}$. These avoided costs represent part of the social or external costs of conventional power plants which if added to the costs of electricity generated by conventional power plants would make the real cost of conventional power much higher than its recent cost and would make wind power economically competitive compared with conventional power plants in Libya.

It can be concluded that the highest saving is the fuel saving, followed by emission saving then the capacity saving.
Therefore, the highest avoided cost is the fuel avoided cost, and then the emission and the capacity avoided costs respectively.

Finally, this project was performed in the middle region of Libya in three sites (Benina, Ejdabia, Sirt) during the period (2009-2019) with penetration of wind power (100MW, 250MW, $500 \mathrm{MW}$ ), and future studies could be performed to include the following:

1. Implementing this study to other sites in Libya.

2- Studying the effect of other penetration levels of wind power over $500 \mathrm{MW}$ on the avoided costs in Libya.

3- Studying the avoided emission costs using other methods such as the effect of these emissions on the environment and expressing these costs as part of the social effect of these emissions on the environment costs.

4- Studying the effect of other social costs and how they can affect the real costs of wind energy and other renewable energy systems when they are internalized in the energy costs.

5- Performing further studies to calculate the feed in tariff to promote wide implementation of wind energy projects and other renewable energy technologies in the national energy mix.

\section{REFERENCES}

[1] Wind Power Economics: Wind Energy Costs- Investment Factors, EWEA Fact sheet. www.ewea.org.

[2] National Energy Data Profile (2007), published by the Libyan National Energy Committee (LNEC), of the World Energy Council (WEC), Bureau of Energy Data and Studies.

[3] Wind Energy and the Environment, Environmental Benefits, External Costs. Local Impacts, Public Acceptance, www.ewea.org.

[4] Pure Power: Wind Energy Scenarios up to 2030 , EWEA, March 2008. 
[5] Environmental Benefits of Wind Energy in Comparison with Remaining Electricity Generation Technologies.

[6] Wind and Climate Fact Sheet, www.gwec.net.

[7] Wind Energy: The Facts, Vol. 2: Costs and Prices.

[8] GECOL, General Expansion planning studies for LIBYA (2008), Final report.

[9] Carbon Dioxide Information Center (CDIAC), http://www.cdiac.ornl.org.

[10] Comparative Air Emissions of Wind and other Fuels, Wind Energy Fact Sheet, AWEA, www awea.org.

[11] Egyptian Environmental Affairs Agency (EEAA)(2002), The Egyptian Pollution Abatement Project (EPAP), Inspection Manual for Energy Generating Plants, pp01-2.

[12] W. I. Abou Zened (2009) Avoided costs by using wind energy in Libya, M.Sc. Thesis, Electrical and Computer Engineering Dept., School of Engineering and Applied Sciences, Academy of Graduate Studies.

[13] Wedad B. El-osta, M. A. Ekhlat, A S.Yagoub, y. khalifa and E. Borass (2005), Estimation of capacity credit for wind power in Libya, Energy Technology and Policy, vol. 3, pp 363-377.
[14] 1996 IPCC Guidelines for National Greenhouse Gas Inventories: Reference Manual.

[15] UN framework convention on climate change http:/unfecc.int

[16] Verification Report, on the Annual Emission Reports 2006, proposed by the Electricity Authority of Cyprus, prepared by TÜV Immissionsschutz und Energiesysteme GmbH, March 14th, 2007

[17] Greenhouse Gas Emission Guidelines: Stationary Combustion Sources, April 2009, www.ncair.org

[18] 2011 Guidelines to Defra / DECC's GHG Conversion Factors for Company Reporting. Aug. 2011, http:/www.defra.gov.uk/environment/ economy/businessefficiency/reporting/

[19] Van Wijk, A. (1990). Wind energy and electricity production, $\mathrm{PhD}$ thesis, University of Utrecht, the Netherlands. 